\title{
Hepatitis Virus
}

National Cancer Institute

\section{Source}

National Cancer Institute. Hepatitis Virus. NCI Thesaurus. Code C14216.

A non-taxonomic classification of unrelated viruses that cause liver inflammation and dysfunction. 